\title{
The Implementation of Scientific Approach in Teaching English Subject at Senior High School of Riau Province
}

\author{
Idham Syahputra ${ }^{1)}$, Hermawati Syarif ${ }^{2),}$ Medyantiwi Rahmawita ${ }^{3)}$ \\ ${ }^{1), 3)}$ UIN Sultan Syarif Kasim Riau, ${ }^{2)}$ Universitas Negeri Padang \\ email: idhamsyahputraaufa@gmail.com ${ }^{1}$, hermawati_sy@yahoo.com ${ }^{2}$, dyan0@gmail.com ${ }^{3}$
}

\begin{abstract}
This study aims to explain the application of a scientific method in teaching English at Riau Province's State Islamic Senior High School 2 (MAN 2). This is a descriptive qualitative study. This study includes one instructor and students from class X. MS.1. Techniques for gathering data include observation, interviews, and documentation. Techniques for data analysis include data reduction, data display, and data verification. The findings of this study suggest that the scientific approach is being used in the teaching of English at State Islamic Senior High School 2 in Riau Province, with the five phases being watching, inquiring, experimenting, associating, and communicating. There are various issues that either stymie or help use the scientific approach in teaching English topics. The time required in five components of the scientific method is an impediment. The next impediment is the material used. Factors that aid in implementation are; interesting material and student effectiveness.
\end{abstract}

Keywords: Scientific Approach, Teaching English

\section{Introduction}

The curriculum is the most important component of the educational system. It serves as a guide for instructors to understand what they should achieve in the teaching and learning process, while the curriculum serves as a guide for students to understand what they should achieve in the learning process. The curriculum is especially significant since it is the key to educational achievement in every country, with each curriculum mapping the demands and potential consequences of the educational process.

Curriculum is constantly evolving. Certain elements, such as economics, politics, and societal expectations, guide the construction of the curriculum. The curriculum evolves to meet the demands of the current age and the expected expectations of the future, resulting in the creation of a good curriculum system that prepares students and learners to achieve good results.

The Curriculum 2013 was published by the Indonesian government in 2013. The Curriculum 2013 is an evolution of the Curriculum 2006, also known as Curriculum-based Competence. According to Permendikbud No. 103/2014, the curriculum-based learning method 2013 is an educational process that allows pupils to build any pattern of learning that happens within the two-way interaction between instructors and students, implying that teachers do not always have to be the more dominating. The curriculum determines the method of educational results. To attain educational goals, an effective and efficient curriculum implementation approach in learning is required. It is necessary to create a paradigm for the teaching and learning process. It frames the teaching learning process by emphasizing on students as the topic who is actively participating in the teaching learning process, hence the term "studentcentered curriculum." The curriculum is being used to adjust the development of science and technology, to develop educational program, and to improve the quality of human resource.

Curriculum changes undoubtedly apply to all courses, including English. The goal of English learning is to improve a person's four language abilities. Teachers must be able to build four language 
skills in their students throughout English learning activities. Regardless of the curriculum established by the government, instructors are always obliged to cultivate four language skills in their students.

Learning in the Curriculum 2013 has a scientific or scientifically oriented approach. Some methodologies, such as contextual learning, can be used in the scientific approach. A learning model is a type of learning that includes names, characteristics, grammar, order, and culture, for example, discovery learning, project-based learning, problem-based learning, and inquiry learning.

The government thinks that by using this strategy, students would be able to enhance their critical thinking skills and use the scientific method to solve any life situation. Students with such critical thinking and problem-solving abilities are expected to be able to adapt to today's life difficulties. Teachers must be able to utilize the Scientific Approach correctly in order for pupils to actively realize their potential. However, some students continue to struggle with the learning process even employing a scientific method.

Riau Province's State Islamic Senior High School is one of the institutions that uses a scientific approach. Since the 2018/2019 school year, this school has been using the 2013 curriculum. Thus, the present curriculum 2013 at Riau Province's State Islamic Senior High School has been in use for four years. The professors conducted training and other seminars in order to discover more about the curriculum 2013. The reality that occurs in the implementation of learning activities English language in State Islamic Senior High School of Riau Province, it appears that when teachers apply the scientific approach in learning there are still some problems faced by teachers and students.

Scientific Approach is particularly relevant to the three learning theories, namely the theory of Bruner, Piaget's theory, and the theory of Vygotsky. Bruner theory of learning is called discovery learning theory. There are four main things related to learning theories of Bruner by Carin \& Sund in Daryanto (2014). They are:

a. Individuals learn and develop his mind only when he uses his mind.

b. By doing cognitive processes in the discovery process, students will gain sensation and intellectual satisfaction which is an intrinsic reward.

c. The only way that a person can learn the techniques of doing discovery is that it has the opportunity to conduct discovery.

d. By making the discovery will strengthen memory retention.

The scientific method consists of five phases. According to Permendikbud No. 103/2014, the scientific approach to learning consists of five steps: watching, inquiring, experimenting or gathering knowledge, associating, and communicating. The 2013 Curriculum's scientific approach is based on scientific method theory. Furthermore, each step is characterized as follows:

\section{Observing}

The first step in a scientific methodology is to observe. The instructor can present a realistic, difficult, and entertaining procedure during this process. According to Hosnan (2014), this method is a learning technique that employs the contextualized approach since it necessitates the usage of media. The goal of this phase is to pique the students' interest so that they will seek further knowledge about a certain issue. During this technique, the instructor allows the pupils to directly view a certain object. The pupils are able to relate the thing that was observed and the subject that will be covered in that meeting by going through this procedure. During this procedure, the instructor may display some photographs or films, or she may even invite the pupils to see a garden/environment firsthand.

The job of the teachers in this process is to supply the items or media that will be observed. Furthermore, teachers create positive atmosphere during the teaching learing activity. According to Hosnan (2014), teachers should make the students participate in the learning process by creating fun, cheerful and enthusiastic situation. 


\section{Questioning}

When applying a scientific method, the second step is to question. This stage tries to pique students' interest so that they will ask questions about the topic. This step's functions are to attract students to the topic being discussed, to stimulate students so that they can be active in classroom activities, to assist students in analyzing their problems and difficulties and also to assist them in obtaining a solution to that problem, and to assist students in thinking critically. According to Hosnan (2014, p. 48), the questioning activity is the method through which students can ask questions about the themes.

According to Hosnan (2014), throughout this process, teachers should help students in creating questions about the issue. The instructor should collect all of the pupils' opinions and aid them in correcting them. The mispronunciation, diction, grammar. In addition, Sani (2015) says that the teachers' job is to increase students' curiosity and stimulate the students by asking some stimulative questions. According to Hosnan (2014), the teachers have the right to correct students' mistakes but they should not make the students feel intimidated and ashamed. The good time to correct the mistakes is after the students give say their opinion. The aim of questioning process is to develop the curiosity from the students. When they are curious about the topic or the objects, they will have willingness to collect the data or addition information about the topic.

\section{Exploring/Collecting Information}

This is the third phase in the scientific method. This is the next phase in the questioning process. The students gather further knowledge on the issue. Students can obtain knowledge via books, media, newspapers, the internet, or even by experimentation. The data or information gathered by students will be used to answer the list of questions posed in the preceding step. According to Hosnan (2014), the process of gathering information is carried out by experimenting, reading other sources, watching other things or occurrences, or interviewing other sources. In this phase, the instructor serves as a facilitator, assisting pupils in gathering knowledge about the topic. During this procedure, teachers may form groups and assign them to gather further information on the topic, which can be in the form of photographs or videos in this case. The information or data can be found by the pupils. In this process, the teachers may form groups and let them find additional information about the topic, or in this case it can be in the form of pictures or videos. The students can find the information or data from other soucers. In this process, teacher's role is to control the learning process and make sure that all of srudents involve in the activity

\section{Associating}

In this stage, students must use the knowledge obtained in the previous step to build on what they have learned. The goal of this phase is to provide pupils with more full and wide information on a certain topic. According to Hosnan (2014), the associating process is one in which pupils cluster the information or concepts they have obtained and associate them into a good memory. Students should utilize the information from the previous stage to assess the questions they created in the second step during this procedure. Following that, students should reach a conclusion based on their analysis. As a result, pupils associate the knowledge from the previous step with specific events connected to the themes and their own experiences, which they subsequently integrate into a good memory.

\section{Communicating}

In this step, the teachers give the chance for the students to communicate what they have learned from the meeting. They make conclusion about the topic that they have in that day. In this activity, the teachers can ask them to write down the summary or tell the summary to friends. According to Hosnan (2014), the teachers' role in this process is to describe or tell the correct information or conclusion from the topic that is discussed. 


\section{Methods}

This study was designed as a case study. Creswell (2012) defines a case study as a qualitative technique in which the researcher delves deeply into a program, event, activity, process, or one or more persons. The case (s) are defined by time and activity, and researchers gather data collecting processes over a long period of time. Case studies will be undertaken in this research to provide an overview of the process of learning English in the classroom. This is connected to the teacher's method of using the scientific approach in English topic instruction so that researchers may gather thorough and in-depth information.

The researcher employs descriptive qualitative research based on the case study design. Suryabrata, Descriptive research is a study that aims to paint a picture of conditions or scenarios and collect fundamental facts in a descriptive manner (2012). According to Creswell (2012), statistics are not employed to examine data in qualitative research; instead, the inquirer analyzes words (e.g., transcriptions from interviews) or images (e.g., photographs). The study was carried out in October 2018 at Riau Province's State Islamic Senior High School. It was on Gobah in Pekanbaru. Teacher is the first participant in this study. Her birthday is December 4th, 1976. She was born in the year 1973 and is 43 years old. Since 2008, she has been teaching English at SMAN Provinsi Riau. Furthermore, she graduated from Universitas Negeri Padang, where Student 1 (S1) is the first RA. She was born on May 5, 2003. She is sixteen years old. Initially, Student 2 (S2) is SKH. She was born on 18 June 2003 She is 16 years old. Students 3 (S3)Students is initially GK. She was born on 26 July 2003 She is 16 years old

To collect the data, the researcher use triangulation technique combining observation and interview. This technique, as stated by Stainback (1988) in Sugiyono (2013), has aim not to determine the truth about some social phenomenon, rather the purpose of triangulation is to increase one's understanding of whatever is being investigated. It means that triangulation aims to increase researcher understanding about social phenomenon and investigate whether the information getting from informant/ participant is wrong as it is not appropriate with theory and law.

\section{Observation}

In the most important observations are the processes of observation and memory Sugiyono (2015). Observation is as a first step to see the application of scientific approach as well as outside class. The type of observation will use is non participative observation, in which case the researcher observed the behavior from afar without any interaction with the subjects Satori \& Komariah (2011). This observation will use to see the process of the implementation of scientific approach in teaching Engish subject at eleventh grade of State Islamic Senior High School of Riau Province.

\section{Interview}

Interviews may be considered as a form of data collection in which unilateral question and answer sessions are conducted methodically and in accordance with study objectives. In general, two individuals are more physically present throughout the interrogation process, and each side may use the communication channels equitably and smoothly.

\section{Documentatation}

According Moleong (2004) documentation is constructed from word "document" that means something either written or film which researcher doesn't prepare before or researcher doesn't take role. The documentation of this research includes : lesson plan, and syllabus. 


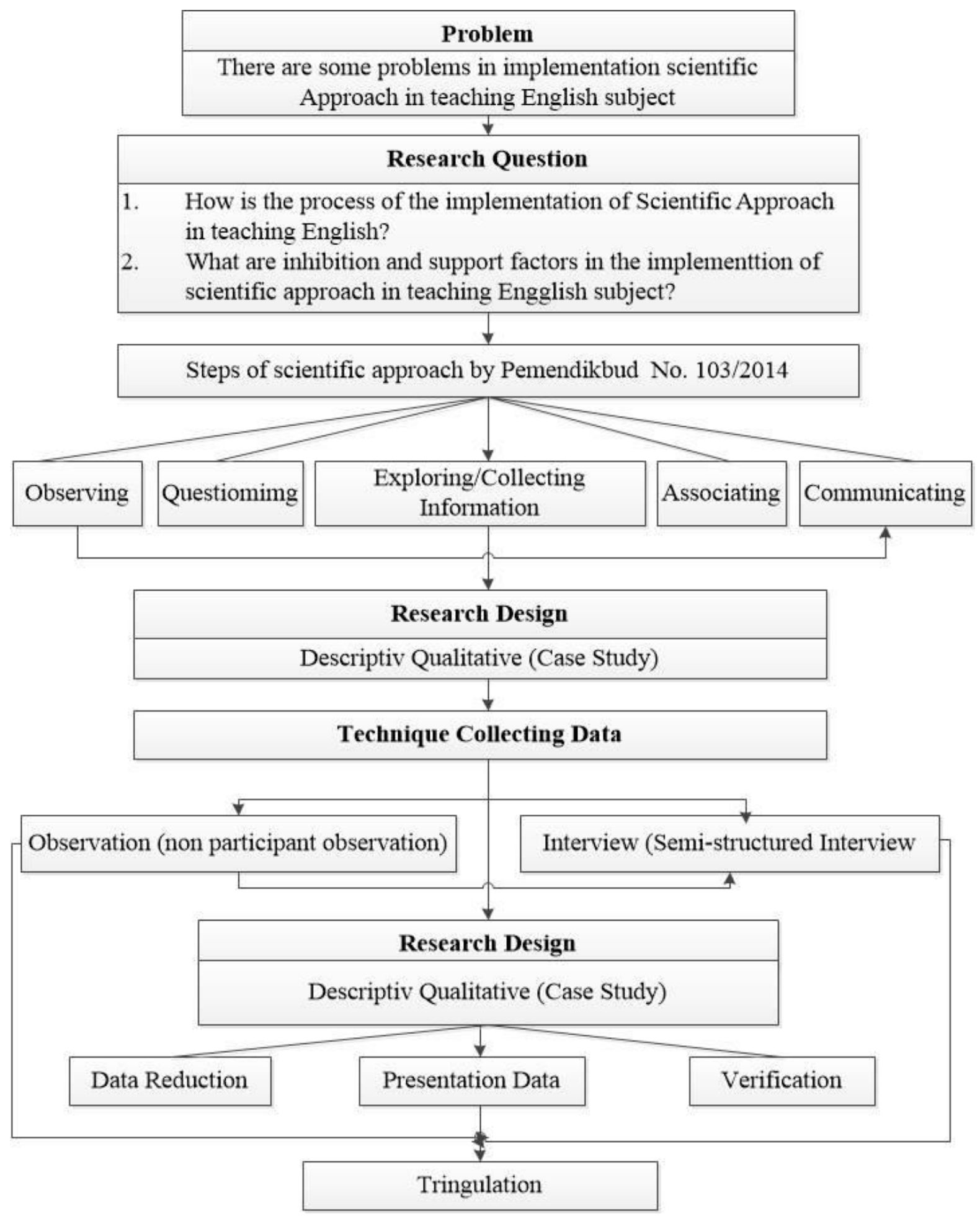

Figure 1. Research Method 


\section{Results and Discussion}

The process of the implementation of Scientific Approach in teaching English subject at tenth grade of State Islamic Senior High School of Riau Province

In the scientific approach there are 5 stages of the implementation process carried out by the teacher, including:

a. Observing

The first stages in the implementation scientific approach is observing. The results of the research implementation of the scientific approach in the observing process can be seen in the lesson plan used by the teacher. The observation data showed:

"Lesson Plan Meeting 1" Pay attention to the videos and pictures about tourism presented by the teacher. (Olp1/D1)

"Lesson Plan Meeting 2" Listening to the teacher's explanation about the noun phrase.(Olp1/D2)

"Lesson Plan Meeting 3" The teacher shows a video about historical buildings while handing worksheets to students. Students read descriptive texts related to historical buildings. Students pay attention to power point shows related to descriptive texts about historical buildings. (Olp/D3)

"Lesson Plan Meeting 4" The teacher shows a video about historical buildings while handing the worksheets to students. Students observe the video given by the teacher and discuss it with the teacher. Students read descriptive texts related to tourist attractions. Students pay attention to power point shows related to descriptive texts about tourist attractions. (Olp1/D4)

Observation data from lesson plan has supported with observation data from classroom activity. The data observation showed:

"class X.Ms 1 day 1" The teacher plays videos and pictures about tourism using the LCD projector in front of the class.Students pay attention to videos and images camly.(Oca1/D1)

"class X.Ms 1 day 2" The teacher asks about the material that was given last meeting.(Oca1/D2)

"class X.Ms 1 day 3" The teacher shows videos about historical buildings. Students observe videos carefully.(Oca1/D3)

"class X.Ms 1 day 4" Students observe the video material given by the teacher. The students pay attention to the power points that the teacher offers related to decriptive text about tourist attractions.(Oca1/D4)

\section{b. Questioning}

In the process of implementing the scientific approach, besides observing aspects there is questioning. The results of the research implementation of the scientific approach in the questioning process can be seen the lesson plan used by the teacher. The observation data showed:

"Lesson Plan Meeting 1" Dipersilahkan mengamati, memberi tanggapan bersama dan saling bertanya mengenai kalimat yang diberikan. Menanyakan informasi yang didapat dengan mencantumkan di LKPD.(Olp2/D1)

Observation data from lesson plan has supported with observation data from classroom activity. The data observation showed:

"class X.Ms 1 day 1" The teacher gives questions and answer with students about the videos and picture they observe. Students answer and respond enthusiastically.(Oca2/D1)

"class X.Ms 1 day 2" Students asked the teacehr what they did not know about material.(Oca2/D2)

"class X.Ms 1 day 3" The teacher asks students for responses to the video that has been observed.(Oca2/D3)

"class X.Ms 1 day 4" The teacher asks students for responses to the video that has been observed.(Oca2/D4) 


\section{c. Exploring/Collecting Information}

In addition to observing and questioning stages, there are stages of exploring / collecting information. The results of the research implementation of the scientific approach in the process of exploring / collecting information can be seen the lesson plan used by the teacher. The observation data showed:

"Lesson Plan Meeting 1" In groups, students identify the text structure and social function in the given text and fill it out on the LKPD sheet. Mention the structure of the text and social functions that have been arranged by showing descriptive text. (Olp3/D1)

"Lesson Plan Meeting 2" The text is given and arranged according to the correct text structure and marks the noun phrase in the text that has been given. (Olp3/D2)

"Lesson Plan Meeting 3" Students work on assignments in the form of completing descriptive texts related to historical buildings by listening to the audio provided by the teacher. (Olp3/D3)

"Lesson Plan Meeting 4" In groups, students are involved in games in the form of compiling descriptive texts related to tourist attractions by pasting the paragraphs provided in front of the class. After compiling descriptive texts, students and their partners make tourism brochures of tourist attractions in their hometowns as attractive as possible. (Olp3/D4)

Observation data from lesson plan has supported with observation data from classroom activity. The data observation showed:

"class X.Ms 1 day 1" The students observe the picture, and students are asked to answer some of questions in the textbook.(Oca3/D1)

"class X.Ms 1 day 2" In group, teacher asked th students to answer some questions related.(Oca3/D2)

"class X.Ms 1 day 3" Students work on assignments in the form of completing descriptive texts related to historical buildings by listening to audio provided by the teacher.(Oca3/D3)

"class X.Ms 1 day 4" In groups, students are involved in games in the form of constructing descriptive texts related to tourist attractions by attaching paragraphs that are provided in front of the class.(Oca3/D4)

\section{d. Associating}

The fourth stage in the scientific approach process is associating. The results of the research implementation of the scientific approach in the process of association can be seen the lesson plan used by the teacher. The observation data showed:

"Lesson Plan Meeting 1" You are welcome to observe, give joint responses and ask each other about the sentences given. (Olp4/D1)

"Lesson Plan Meeting 2" In the group discuss the descriptive linguistic elements of the text, namely noun phrases. (Olp4/D2)

"Lesson Plan Meeting 4" In groups, students are involved in games in the form of compiling descriptive texts related to tourist attractions by pasting the paragraphs provided in front of the class. (Olp4/D4)

Observation data from the lesson plan has been supported with observation data from classroom activity. The data observation showed:

"class X.Ms 1 day 1" The teacher divided the class into groups. It consists of five students in each group.(Oca4/D1)

"class X.Ms 1 day 2" in groups of students discuss the worksheets were given by the teacher.(Oca4/D2)

"class X.Ms 1 day 3" Students and teachers discuss the video observed. (Oca4/D3)

"class X.Ms 1 day 4" Students and teachers discuss the material obtained in the video.(Oca4/D4) 


\section{e. Communicating}

The fifth stage in the scientific approach process is communicating. The results of the research implementation of the scientific approach in the communicating process can be seen the lesson plan used by the teacher. The observation data showed:

"Lesson Plan Meeting 1" Together with the teacher discuss the answers that have been prepared in each group. Students communicate their work in front of the class. (Olp5/D1)

"Lesson Plan Meeting 2" Discuss with the teacher about the results they get. (Olp5/D2)

"Lesson Plan Meeting 3" Students communicate the results of the analysis of the descriptive text in front of their classmates. (Olp5/D3)

"Lesson Plan Meeting 4" Students communicate the descriptive text in front of their classmates. (Olp5/D4)

Observation data from the lesson plan has been supported with observation data from classroom activity. The data observation showed:

"class X.Ms 1 day 1" The teacher asked one of the students to stand up and read it loudly. The teacher ask the student to explain the content of each paragraph. The teacher invites the students to conclude they have learn.(Oca5/D1)

"class X.Ms 1 day 2" the teacher evaluates to see students acceptance of the material by invite the students to conclude they have learned.(Oca5/D2)

"class X.Ms 1 day 3" Students then present the descriptive text analysis results in front of classmates. The teacher gave an evaluation related to the descriptive text of historical buildings. (Oca5/D3)

"class X.Ms 1 day 4" Teacher asks one of the students to stand up and read it loudly the assignments they make.(Oca5/D4)

Based on the first and the last observation, the teacher applied a scientific approach. In the first until last observation, the teacher used five phases those are: observing, questioning, experimenting, associating, and communicating. So, the teacher can implement five phases, those are: observing, questioning, experimenting, associating, and communicating.

\section{The inhibition and support factors of implementation of Scientific Approach in teaching English subject at tenth grade of State Islamic Senior High School of Riau Province}

The inhibition and support factors of implementation of scientific approach in teaching English, the teacher answered that there were 2 inhibiting factors in the process of implementing the scientific factors.

The first factor is material, the teacher says not all material can use all aspects in the scientific approach. The second factor is time, according to the teacher in one of the scientific approaches that can take a long time in the learning process. The teacher also said that he must be able to control the good time so that the five aspects in the scientific approach are in accordance with the RPP. It can be seen from the interview as follows:

Interviewee: In terms of time, from the 5 steps of the scientific approach, sometimes one of the steps takes more time. So must be able to set the time.(If1/T)

Interviewee: the inhibiting factor is in terms of material, because not all materials can be carried out using the scientific approach. (If $2 / \mathrm{T}$ )

Then, the researcher asked students about the inhibition and support factors in learning english prosess. The researcher got the result like their answer as follows:

Interviewee: Hmmmm.. What's the inhibiting factor... Maybe in terms of time, sis.. Sometimes the time is not enough to do the assignments from the teacher..(If1/S1) 
Interviewee: The inhibiting factor? Hmm.. what is it, sis, usually there is not enough time to discuss 1 material, sis... that's it, sis.. sometimes the time for doing assignments is also not enough... hhhmmm...(If1/S2)

Interviewee: Oooo the inhibiting factor, sis, there is not much time, sis.. hehehe..(If1/S3)

Interview data has been supported with the headmaster. Headmaster statement showed:

Interviewee: In the scientific approach, there are several stages.. and some teachers still have difficulty managing time, sometimes it may be only a few steps that can be applied in one meeting..(If $1 / \mathrm{Hm})$

Interview data has been supported with vice curriculum. Vice curriculum statement showed:

Interviewee: For the implementation of the RPP, the teacher will process it directly, so far there have been no problems with the English teacher and other teachers. But for English, it is time constrained, because for English subjects the meeting time is not as much as other subjects. So the teacher must be able to manage time with the material in each meeting. (If $1 / \mathrm{Vc}$ )

Next, the teacher answers questions about support factors of implementing of scietific approach in teaching English. The teacher says that active students are a supporting factor in the implementation of the scientific approach. It can be seen from the interview as follows:

Interviewee: For the supporting factors from active students, the more active students are, the better the scientific approach process itself is. (Sf1/T)

Interviewee: If the supporter is, maybe the class is active, bro.. usually in discussions, if the friends are active, the learning process becomes more fun and smooth, sis.. maybe that's all bro..(Sf1/S2)

Interview data has been supported with the headmaster. Headmaster statement showed:

Interviewee: The teacher supports it, the more creative the teacher gives interesting material that makes the students more active. (If $1 / \mathrm{Hm}$ )

Based on the interview, it can conclude that in scientific approach it has 2 dedications in its implementation, namely time and material in its use. Supporting factors are interesting material and active students who make the implementation of the scientific approach good.

The researcher discovered the impediments to the implementation of the Scientific Approach in teaching English at the tenth grade of the State Islamic Senior High School of Riau Province in this study. It is based on interviews with teachers, students, the headmaster, and the vice curriculum.

According to the interviews with the instructor and students, the time and material employed in the scientific approach are inhibiting elements in the scientific approach. More time and resources were allocated to the scientific approach's execution.

The scientific method, in addition to having inhibiting elements, also includes supportive aspects, namely the material and the activeness of pupils. Students that are drawn to the topic are more engaged in the learning process. Then there are students who actively inspire other pupils to be more motivated.

\section{Conclusion}

There is some inhibition and support factors in the implementation of scientific approach in teaching English subject. The inhibition factors are the time use in the five aspects in the scientific approach. Every aspect must be able to manage time well. The next inhibition factors is the material that uses. Not all the phase could not always implement fully. The support factors in the implementation of scientific approach in teaching English subject are the material that is interesting and the activity of other students that makes students more active and motivated students.

\section{References}

Barret, Terry (2006). Understanding Problem-Based Learning. Barrett, T., Mac Labhrainn, I., Fallon, H. (Eds). Handbook of Enquiry \& Problem Based Learning. Galway: CELT. 
Creswell, J. W. (2012). Educational research: Planning, conducting, and evaluating quantitative and qualitative research (4th ed.). Boston: Pearson.

Daryanto. (2014). Pendekatan pembelajaran saintific kurikulum 2013. Yogyakarta: Gava Media.

Emzir. (2012). Metode penelitian kualitatif: Analisis data. Jakarta: Rajawali Grafindo Persada.

Hadi, S. (2003). Metodologi research. Yogyakarta: Andi.

Hosnan, M. (2014). Pendekatan saintifik dan konstektual dalam pembelajaran abad 21. Bogor: Ghalia Indonesia.

Kartika, Y. (2015). The implementation of scientific approach in teaching English at Eight Grade of SMP Muhammadiyah 10 Surakarta in 2014/ 2015 Academic Year: A Naturalistic Study. Surakarta: Muhammdiyah University of Surakarta.

Made, W. (2009). Strategi pembelajaran inovatif kontemporer: Suatu tinjauan konseptual operasional. Jakarta: Bumi Aksara.

Moleong, Lexy J. (2004). Metodologi penelitian kualitatif. Bandung: PT. Remaja Rosdakarya.

Muh. Rais. (2010). Project based learning: Inovasi pembelajaran yang berorientasi soft skills. Surabaya: Unesa.

Musfiqon, \& Nurdyansyah. (2015). Pendekatan pembelajaran saintifik. Sidoarjo: Nizamia Learning Center.

Hanafiah, N., \& Suhana, C. (2009). Konsep strategi pembelajaran. Bandung: Refika Aditama.

Nurdin, S., \& Adriantoni. (2016). Kurikulum dan pembelajaran. Jakarta: Raja Grafindo Persada.

Puspita, E. D. (2016). ELESP students problems in implementing scientific approach during practice teaching program. Yogyakarta: Sanata Dharma University.

Sani, R. A. (2015). Pembelajaran saintifik untuk implementasi kurikulum 2013. Jakarta: Bumi Aksara.

Satori, D. \& Komariah, A. (2011). Metodologi penelitian kualitatif. Bandung: Alfabeta.

Sugiyono. (2015). Metode penelitian kuantitatif, kualitatif, dan $R \& D$. Bandung: Alfabeta.

Trianto. (2014). Model pembelajaran terpadu: Konsep, strategi, dan implementasinya dalam Kurikulum Tingkat Satuan Pendidikan (KTSP). Jakarta. Bumi Aksara. 